excess water and improvements in mechanical and industrial operations, the air-drying of peat by natural means is the only recognised commercially successful method in use to-day. Reduction of the water-content from 90 to 70 per cent. by pressure alone on the raw peat is considered by the author to be the maximum, and he does not consider that drying by artificial heat becomes a practical proposition until this $7^{\circ}$ per cent. content is reached, "and even then it is a very doubtful financial proposition."

For use under boilers the water should be reduced to $30-35$ per cent.; for gas producers it is stated that several leading manufacturers claim successful working with $60-70$ per cent., but Prof. Purcell considers that the possibility of using peat with as high a moisture-content as 60 per cent. is doubtful, and quotes the Canadian authority, Haakel, in support. "If it were permissible [to use such wet peat] it would render the industry less dependent on the weather, extend the peat-winning season, and simplify the whole problem."

Prof. Purcell considers that a clear case for the extended development of the peat deposits exists from an agricultural point of view, for the reclamation of land by removal of the bog and drainage must add to the food-proaucing capacities of a country. But labour costs are no small difficulty, for, as Sir George Beilby points out in his introduction, the development of a bog with $20 \mathrm{ft}$. of good peat is in some respects analogous to the proposal to develop a coalfield of similar area containing a single seam of only ${ }_{15}$ in. thickness. It is true that the peat bog entails only surface working, but the whole depth has to be worked and Io tons of raw material excavated and handled for I ton of dry peat.

J. S. S. B.

\section{Past and Present Sewage Systems.}

$T$

WO Chadwick public lectures recently delivered at Colchester by Mr. A. J. Martin dealt with the nature and treatment of sewage. Since the very earliest days there have been codes of sanitary laws, but all kinds of readjustments had to be made as soon as men began to congregate in large cities. 'ihese crowded conditions seem to be met most satisfactorily by the water-carriage system, by which the clean water supplied to a town returns ultimately to the sewers charged with all manner of pollution. When sewers were first laid the sewage was discharged straight into the rivers. The results were, of course, disastrous, and successive Royal Commissions were set up to find a remedy. The whole problem of sewage purification was obscure, and very little progress was made for a whole generation. Great hopes were centred in sewage farms as a method of disposing of the sewage, and the various local authorities hoped at the same time to reap a profit from the cheap manuring of the land. Sewage farms, however, rarely pay in a humid climate such as ours, for the land cannot deal with the huge amounts of water brought down from the sewers. Many other methods were tried, but in all of them the investigators failed to recognise the existence of the tiny scavengers which Nature provides to deal with our waste products.

The modern method of sewage purification was evolved after Pasteur's discovery of the bacteria which induce fermentation, and after the work of Warington and of Winogradsky on the nitrifying bacteria in the soil. The purification is carried out in two stages. The first stage is treatment in the "septic tank," through which the sewage passes extremely slowly. The solids sink NO. 265 I, VOL. IO5] to the bottom, where they are attacked by anaerobic organisms flourishing there, and ultimately either liquefied or turned into gas. The second stage of the process consists in the oxidation of the dissolved polluting matter. This matter has to be brought into contact with a large supply of atmo. spheric oxygien in the presence of certain small organisms which are able to oxidise the organic materials. This contact may be effected in the soil, in a specially constructed filter, or in a large volume of water. When soil forms the contact bed, purification is brought about either by "filtration," when the sewage percolates downwards through the soil, or by "broad irrigation," when the sewage merely passes over the soil surface. The method chosen depends on the openness or otherwise of the soil and subsoil. When suitable land is not available, artificial filters are made of broken clinker, destructor slag, etc. These materials provide a home for the nitrifying bacteria. The sewage is allowed to trickle slowly through, and with a good filter a purification of $8 \mathrm{c}-90$ per cent. is effected. When purification is allowed to take place in water, the volume of the water into which the sewage flows needs to be about five hundred times greater than the volume of the sewage.

Engineers had just settled down to the septic tank and trickling filter as the standard method for sewage purification when the "activated sludge" process was introduced by Drs. Fowler and Ardern. In this process the whole purification is completed in a tank provided with particles of activated sludge to serve as homes for the nitrifying bacteria. The sludge (i.e. solid deposit from the sewage) is activated by being submitted to currents of air for several days. It is then placed in the tank with the sewage, and air forced through for some hours until purification is effected. The drawback of this method is the great bulk of the resultant sludge, and the problem now is to find an economical way of disposing of the sludge so that the plant-food which is contained in sewage shall not be wasted.

\section{Experimental Cottage Building.}

I $N$ view of the present housing difficulties, considerable interest has been centred in the results of the experiments in cottage building which have been carried out on the Ministry of Agriculture's Farm Settlement at Amesbury. These results are published in the Weekly Services for May $I_{5}$ and 22 , where we also learn that on Wednesdays for two or three months competent guides have been available to show visitors the experiments actually in progress. The present scheme includes thirty-two cottages, sixteen of which are for comparison purposes, and are built of brick on normal lines of construction, while the other sixteen are more directly experimental. Each cottage consists of parlour, livingroom, scullery, bath-wash-house, larder, fuel store, etc., on the ground floor, with three bedrooms on the upper floor. Experiments in building in chalk include a cottage with cavity walls built of blocks made of chalk and cement, one with walls of chalk and cement rammed between shuttering, one with walls of chalk alone (chalk pisé), and one with walls of chalk and straw (chalk cob) built without shuttering. There is also one cottage of monolithic reinforced concrete and two concrete-block cottages with hollow walls. These two cottages are being erected under contract by two proprietary firms; for all the other experimental cottages direct labour is employed. The experiment also includes a pair of timber-framed cottages faced with 
elm weather-boarding and two Army ruts converted into permanent bungalows. With regard to the latter experiment, results show that no economy is effected by using these huts. Another cottage has walls of clay and gravel, while two single and one pair of cottages are being erected in pisé-de-terre. One of the single pisé cottages is now being roofed-this is the first two-storied pisé house erected in England.

Pisé-de-terre walls are built by ramming nearly dry soil between movable shutters arranged as a temporary mould. The method was known in England a century ago, but had. fallen into disuse, and a large number of investigations have been carried out to determine the best lines for its revival. All soils are not suitable for pisé work, for not only must the particles cohere firmly when rammed and dried, but also there must be no excessive shrinkage in the drying process. Calcium carbonate helps to reduce shrinkage, while organic constituents are particularly liable to shrinkage, and therefore weaken coherence in the soil as a whole. The amount of water present in the soil at the time of use is an all-important factor. Generally speaking, this water should be between 7 per cent. and 14 per cent. of the weight of the dried earth. The most suitable method of shuttering and the best form of rammer have been decided, while experiments are also being made to find the most satisfactory material and method for rendering the exterior face of the wall. Pisé building can be carried out in the winter if there is sufficient protection from severe weather, but consideration of the expenses involved in providing tarpaulins, screens, etc., makes it evident that it is not sound economy to undertake pisé construction in the winter months. When building in pise the foundations have to be of brick or concrete; the pisé work mav be started only at about 9 in. to I $\mathrm{ft}$. above the ground-level. This is an important factor in the consideration of the cost of pisé building, which. however. will probably prove to be a considerably cheaper process than building in brick.

\section{Cotton Growing.}

THE Empire Cotton Growing Committee of the Board of Trade, which presented its first report on cotton growing in the British Empire in lanuary last (Nature, February 26 and March 25), has now published a note on "Future Organisation," which may be regarded as an appendix to the report. While it is merely indicative. of the trend of the Com. mittee's ideas, in that such organisation is subject to the appointment of the director and his staff, it makes the situation more definite by estimating the probable expenditure upon the various branches of work contemplated.

As in the case of the original report. all the organisation proposed is for common service, since the expenditure can bring no direct return, but it should, in the Committee's opinion, indirectly brings about an increase in the cotton supplies. The Committee concludes that in order to carry out the work adequately an annual sum of approximately 200,00ol. ought to be assured. This amount may appear large until we remember that cotton to the value of about $50.000,000$. is imported into this country annually.

The note sketches the proposals for finance and superior organisation, executive work, and the eentral office; for staff abroad; for supplementing staffs of agricultural departments oversea, and pioneering; for education and information; and for commercial handling. In the last case the setting up of semicommercial experimental enterprises is excluded from the scope of the note. Amongst these headings the Conmittec proposes an initial expenditure of $20,000 l$. per annum upon its own research station abroad. It also proposes to provide for a staff of ninety men, including scientific workers and agricultural officers of different grades, for the purpose of supplementing local agricultural department staffs " after full consultation with and on invitation by the local administration."

Under the heading of "Education" the Committee makes proposals which take the initiative in a move towards obtaining co-operation between all the plantusing industries in order to increase the facilities for training men in pure science, later to be of economic value to the various agricultural services abroad. It estimates that university staffs in this country should be increased specially for this purpose by at least four professorships, fifteen lectureships, and six administrative and technical lectureships, together with a provision of twenty post-graduate studentships. The annual cost is estimated at $27,000 l$., of which it is suggested that the rotton industry should contribute $12,000 l$, as its share.

\section{Thermostatic Metal.}

THE British Thomson-Houston Co., Ltd., has sent I. us specimens of a new bimetallic strip for use in thermostatically controlled devices. The strip is prepared by the permanent union over their entire length of two metals with widely differing coefficients of expansion. The union between the two component metals is complete and durable, and the strip may be bent, twisted, or hammered without causing the separation of the metals at any point, and even on heating the bond will not be broken so long as the temperature remains below the melting point of the softer of the two metals. Owing to this permanency of union the metal can be formed into any desired shape, annealed after formation, and safely emploved at any temperature below $500^{\circ} \mathrm{F}$. The component metals do not corrode under ordinary conditions, and may be used in any reasonable situation without fear of deterioration or change in operating characteristics. The amount of deflection obtained is alwavs the same in a strip of given length and thickness for a given temperature change, and consequently the strip provides a trustworthy basis for the operation of any thermostatic device. and may be emploved for work of high precision. The deflection due to temperature change varies inversely as the thickness, directly as the square of the length, and directly as the temperature change. With a strip $A$ in. long, $0.3 \mathrm{I}$ in. wide, and 0.03 in. thick the deflection obtained for a temperature change of $100^{\circ} \mathrm{F}$. is about $0.57 \mathrm{in}$. The force exerted varies as the square of the number of degrees of temperature change and as the square of the thickness, and directlv as the width, and is not affected by changes of length. For a strip of the dimensions above-mentioned the force exerted for $100^{\circ} \mathrm{F}$. change of temperature is about $3.0 \mathrm{z}$. weight, whereas for a strip of the same dimensions but $0 . \mathrm{I}$ in. thick the force exerted is about $24 \mathrm{oz}$. weight. To produce a permanent set in a strin 4 in. long, $0.3 \mathrm{I}$ in. wide, and $0.02 \mathrm{in}$. thick a force of about $7 \mathrm{oz}$. weight would be required. The metal is manufactured in standard sizes ranging from 0.015 in. to 0.25 in. in widths up to 6 in. and lengths up to 36 in. It can, however, generally be supplied cut to widths and leneths to suit the purchaser, and in special cases thermostatic metal parts mav be completely formed to the purchaser's specifications. 